\title{
Prodynorphin-Derived Peptides Are Critical Modulators of Anxiety and Regulate Neurochemistry and Corticosterone
}

\author{
Walter Wittmann ${ }^{1,4}$, Eduard Schunk', Iris Rosskothen', Stefano Gaburro ${ }^{2}$, Nicolas Singewald ${ }^{2}$, \\ Herbert Herzog ${ }^{3}$ and Christoph Schwarzer*,I
}

'Department of Pharmacology, Innsbruck Medical University, Innsbruck, Austria; ${ }^{2}$ Department of Pharmacology and Toxicology, Institute of Pharmacy and Center for Molecular Biosciences Innsbruck, University of Innsbruck, Innsbruck, Austria; ${ }^{3}$ Neuroscience Program, Garvan Institute of Medical Research, Darlinghurst, NSW, Australia

\begin{abstract}
Stress and anxiety are mainly regulated by amygdala and hypothalamic circuitries involving several neurotransmitter systems and providing physiological responses to peripheral organs via the hypothalamic-pituitary-adrenal axis and other pathways. The role of endogenous opioid peptides in this process is largely unknown. Here we show for the first time that anxiolytic parameters of explorative behavior in mice lacking prodynorphin were increased 2-4-fold in the open field, the elevated plus maze and the light-dark test. Consistent with this, treatment of wild-type mice with selective $\kappa$-opioid receptor antagonists GNTI or norbinaltorphimine showed the same effects. Furthermore, treatment of prodynorphin knockout animals with $U-50488 \mathrm{H}$, a selective $\kappa$-opioid receptor agonist, fully reversed their anxiolytic phenotype. These behavioral data are supported by an approximal 30\% reduction in corticotropin-releasing hormone $(\mathrm{CRH})$ mRNA expression in the hypothalamic paraventricular nucleus and central amygdala and an accompanying 30-40\% decrease in corticosterone serum levels in prodynorphin knockout mice. Although stress-induced increases in corticosterone levels were attenuated in prodynorphin knockout mice, they were associated with minor increases in depression-like behavior in the tail suspension and forced swim tests. Taken together, our data suggest a pronounced impact of endogenous prodynorphin-derived peptides on anxiety, but not stress coping ability and that these effects are mediated via $\kappa$-opioid receptors. The delay in the behavioral response to $\kappa$-opioid receptor agonists and antagonist treatment suggests an indirect control level for the action of dynorphin, probably by modulating the expression of $\mathrm{CRH}$ or neuropeptide $\mathrm{Y}$, and subsequently influencing behavior.

Neuropsychopharmacology (2009) 34, 775-785; doi:I0.1038/npp.2008.142; published online 17 September 2008
\end{abstract}

Keywords: amygdala; $\kappa$-opioid receptor; hypothalamic-pituitary-adrenal axis; stress; prodynorphin knockout; paraventricular nucleus

\section{INTRODUCTION}

Cerebral control of stress and anxiety depends on several brain areas including the amygdala and the hypothalamus. These nuclei use the hypothalamic-pituitary-adrenal (HPA) axis as common output pathway, regulating the physiological response via ACTH and corticosterone release. Besides the classical transmitter systems such as serotonin or catecholamines, several neuropeptide systems are also considered to be involved in generating symptoms of depression, anxiety, and stress. Corticotropin-releasing hormone $(\mathrm{CRH})$ is thought to be a key player, with potential influence of other peptides such as neuropeptide Y (NPY), cocaine and amphetamine-regulated transcript (CART) and substance P. Intraventricular injection of $\mathrm{CRH}$ or overexpression of $\mathrm{CRH}$ is anxiogenic in mice

\footnotetext{
*Correspondence: Dr C Schwarzer, Department of Pharmacology, Innsbruck Medical University, Peter-Mayr-Str. Ia, A-6020 Innsbruck, Austria, Tel: + 435129003 71205, Fax: + 43512900373200 ,

E-mail: schwarzer.christoph@i-med.ac.at

${ }^{4}$ Current address: Department of Anatomy and Structural Biology,

University of Otago, Dunedin, New Zealand
}

(Stenzel-Poore et al, 1996). Inactivation of CRH receptor 1 reduces anxiety (Smith et al, 1998; Timpl et al, 1998). In contrast, deletion of CRH receptor 2 is anxiogenic without affecting basal HPA axis activity (Bale et al, 2000; Coste et al, 2000; Kishimoto et al, 2000). NPY is mostly reported as the counterpart of $\mathrm{CRH}$, producing opposing effects and thereby potentially balancing the emotional state (for reviews see Heilig et al, 1994; Sajdyk et al, 2004). CART and substance $\mathrm{P}$ both elicit anxiogenic effects (for reviews see Ebner and Singewald, 2006; Stanek, 2006). One of the less understood players in emotional control is the opioid system. This depends partially on the complexity of the system comprised of a variety of neuroactive peptides derived from three independent gene products that all act on three different classical opioid receptors. In addition, also direct effects of opioids on NMDA receptors were proposed (Wollemann and Benyhe, 2004). Contradictive data from pharmacological studies may result from this complexity.

There is evidence that dynorphin modulates emotional control. Tsuda et al (1996) proposed an involvement of KOR in the anxiolytic action of diazepam. Chronic pain 
induces anxiety in mice, which is associated with increased KOR-specific binding in the amygdala. On the other hand, Narita et al (2006) showed in the same study marked anxiolytic effects of KOR agonists. Also big dynorphin (a precursor peptide consisting of dyn A and B) was suggested as anxiolytic peptide (Kuzmin et al, 2006). In contrast Knoll et al (2007) proposed anxiolytic effects of KOR antagonists in rats. Dynorphins are released during stress and prodynorphin deletion influences stressinduced behavior (McLaughlin et al, 2003) and the $\kappa$-opioid receptor was made responsible for the dysphoric component of stress (Land et al, 2008). Very recently, Bilkei-Gorzo et al (2008) reported increased startle-response and somewhat reduced exploratory behavior on the zero-maze in dynorphin knockout mice, suggesting an anxiogenic phenotype. This was opposed by reduced stress-induced hyperthermia and unchanged explorative behavior in the light-dark test. In the same study Bilkei-Gorzo et al (2008) report control of hormonal stress reactivity by endogenous enkephalins and dynorphins, but suggested enkephalin as most important opioid peptide in anxiety control.

However, we still know only very little about the impact of endogenous dynorphin on emotional control. The distribution of prodynorphin in the brain overlaps with areas involved in emotional control (Lin et al, 2006; Marchant et al, 2007). In the present study, we undertook combined neurobiochemical, hormonal and behavioral investigations on prodynorphin knockout mice $\left(\mathrm{dyn}^{(-/-)}\right)$to determine and clarify the role of endogenous prodynorphin-derived peptides in anxiety and stress behavior.

\section{MATERIALS AND METHODS}

\section{Animals}

The generation of $\mathrm{dyn}^{(-/-)}$mice was described recently (Loacker et al, 2007). Mice were backcrossed onto the C57Bl/6N background over 8-10 generations and wild-type littermates were used as controls. Partially commercial C57Bl/6N (Charles River, Sulzfeld, Germany) were used in pharmacological experiments. The data obtained from these animals were indistinguishable from wild-type mice of our breeding. For breeding and maintenance mice were group housed with free access to food and water. Temperature was fixed to $23^{\circ} \mathrm{C}$ and $60 \%$ humidity with a $12 \mathrm{~h}$ light-dark cycle (lights on $0700-1900$ hours). Age and testing experience matched male mice at 3-8 months age were tested in all experiments. All procedures involving animals were approved by the Austrian Animal Experimentation Ethics Board in compliance with the European convention for the protection of vertebrate animals used for experimental and other scientific purposes ETS no.: 123. Every effort was taken to minimize the number of animals used.

\section{Physical Exam}

To investigate the general constitution we performed a systematic basic characterization of the prodynorphin knockout mice in regard to their physical conditions, sensory abilities, and motor functions. This exam (Crawley,
1999; Karl et al, 2003) comprised the wire-hang test (1 min $30 \mathrm{~cm}$ elevated) to check muscular strength and RotaRod (20 s 0 -10 r.p.m., subsequently increasing over $60 \mathrm{~s}$ from 10 to 30 r.p.m.) for motor coordination and balance. Visual cliff and acoustic response tests were performed for sensory abilities. Basic behavior was evaluated in an empty cage for $1 \mathrm{~min}$, observing running, jumping, circling, freezing, rearing, defecation, urination, and grooming. Basal activity and circadian rhythm of wild-type and $\mathrm{dyn}^{(-)}$mice was monitored in their home cages using the Infra-Mot system (TSE, Bad Homburg, Germany). Animals were observed for two dark-light cycles after an initial accommodation phase of several hours.

\section{Behavioral Testing}

If not stated differently, mice were single housed 7 days before testing and transferred to the testing facility $24 \mathrm{~h}$ before commencement of experiments. Tests were performed between 0900 and 1300 hours. All tests were video monitored and evaluated by an experimenter blinded to the genotype of animals.

Open field. Open field behavior was tested over $10 \mathrm{~min}$ in a $50 \times 50 \mathrm{~cm}$ flexfield box equipped with infrared rearing detection. Illumination was set to 150 lux. Animals were video monitored and their explorative behavior was analyzed using the Video-Mot 2 equipment and software (TSE-systems, Bad Homburg, Germany). Arenas were subdivided into border (up to $8 \mathrm{~cm}$ from wall), center $(20 \times 20 \mathrm{~cm}$, ie $16 \%$ of total area), and intermediate area according to the recommendations of EMPRESS (European Mouse Phenotyping Resource of Standardised Screens; http://empress.har.mrc.ac.uk).

Elevated plus maze. Behavior was tested over $5 \mathrm{~min}$ on an elevated plus maze $1 \mathrm{~m}$ above ground consisting of two closed and two open arms, each $50 \times 5 \mathrm{~cm}$ in size. The test instrument was build from gray PVC, the height of closed arm walls was $20 \mathrm{~cm}$. Illumination was set to 180 lux. Animals were placed in the center, facing to an open arm. Analysis of open and closed arm entries and time on open arm was automatically done with Video-Mot 2 equipment and software.

Light-dark test. Explorative behavior in a brightly lit area (150 and 400 lux) was investigated by insertion of a black box into the open field arena, covering one third of the space. Time spent and distance traveled was measured over a $10 \mathrm{~min}$ period in the open area. One small field directly at the entrance to the black box was assigned as transition zone. To reach the larger compartment assigned as open area, the mouse had to leave the dark area completely.

Forced swim test. Mice were tested for an initial 15 min trial and the next day in four repeats of $6 \mathrm{~min}$ trials. To increase stress we performed the test in $25^{\circ} \mathrm{C}$ water with $2 \mathrm{~h}$ interval for the second day trials. Immobility, defined as no activity for at least $2 \mathrm{~s}$ was evaluated from video clips for the final $4 \mathrm{~min}$ of each trial independently by two investigators blinded to the genotype of animals. 
Tail suspension test. The tip $(\sim 1.0-1.5 \mathrm{~cm})$ of the tail of mice was securely fastened with medical adhesive tape to a metallic surface. Mice were suspended for $6 \mathrm{~min}$ approximately $30 \mathrm{~cm}$ above the surface. The illumination on the floor of the table was 100 lux. Immobility (lasting over $2 \mathrm{~s}$ ) and latency to the first immobile phase of the mice was evaluated. This test was performed in accordance to the recommendations of EMPRESS, with some adaptations for video monitoring instead of automatic evaluation.

Stress-induced hyperthermia. A temperature probe, lubricated with glycerol, was inserted into the rectum of the mouse for a depth of up to $2 \mathrm{~cm}$. The temperature probe remained in the animal till a stable temperature was reached (maximum $10 \mathrm{~s}$ ). Temperature measurement was repeated after $10 \mathrm{~min}$ and the rise in temperature between the first and second measurement was considered as stress-induced hyperthermia (Olivier et al, 2003).

Flinch test. Animals were placed in a chamber with a floor of metal bars and subjected to $1 \mathrm{~s}$ shocks of gradually increasing amperage starting from $0.05 \mathrm{~mA}$ and successive increment of $0.05 \mathrm{~mA}$ with $30 \mathrm{~s}$ inter-shock intervals. Mice were scored for their first visible response to the shock (flinch-1 paw lifted), their first severe motor response (run or jump), and their first vocalized distress (scream).

\section{Opioid Receptor Pharmacology}

The KOR antagonists norBinaltorphimine (norBNI) and $5^{\prime}$-guanidinyl-17-(cyclopropylmethyl)-6,7-dehydro-4,5 $\alpha$-epoxy3,14-dihydroxy-6,7-2', $3^{\prime}$-indolomorphinan dihydrochloride (GNTI) and the selective KOR agonist trans-(-)-3,4dichloro- $N$-methyl- $N$-(2-(1-pyrrolidinyl)cyclohexyl) benzeneacetamide hydrochloride (U-50488H) were purchased from Tocris Cookson. GNTI shows higher KOR selectivity and antagonist potency than norBNI (Jones and Portoghese, 2000). All drugs were dissolved in saline and $\mathrm{pH}$ was adjusted to 7.2 . NorBNI $(10 \mathrm{mg} / \mathrm{kg})$ and $\mathrm{U}-50488 \mathrm{H}(2.5 \mathrm{mg} /$ $\mathrm{kg}$ ) were given intraperitoneally (i.p.) at different intervals. GNTI was given intracisternally ( $3 \mathrm{nmol}$ in $3 \mu \mathrm{l}$ ) $20 \mathrm{~h}$ before testing under mild sevofluoran anesthesia. Drug doses and application times were chosen according to recent studies in mice (Jewett et al, 2001; Solbrig et al, 2006).

\section{In Situ Hybridization}

For in situ hybridization the following custom synthesized (Microsynth, Balgach, Switzerland) DNA oligonucleotides complementary to mouse mRNAs were used: NPY: $5^{\prime}$ GAGGGTCAGTCCACACAGCCCCATTCGCTTGTTACCTAG CAT-3'; CRH: 5'-CCGATAATCTCCATCAGTTTCCTGTTGC TGTGAGCTTGCTGAGCT-3'; Orexin: 5'-GAATCGTCTTTA TTGCCATTTACCAAGAGACTGACAGCGGCGAGC-3'; preprotachikinin A (PPTA): 5'-ATCGTTGGCATCGATTTCCTC TGCAAACAGTTGAGTGGAAACGAG-3'; CART: 5'-TCCTT CTCGTGGGACGCATCATCCACGGCAGAGTAGATGTCCAG G-3'; proopiomelanocortin (POMC): 5'-TGGCTGCTCTCC AGGCACCAGCTCCACACATCTATGGAGG-3'; agouti-related protein (AgRP): 5'-AGCTTGCGGCAGTAGCAAAAGG CATTGAAGAAGCGGCAGTAGCAC-3'; thyrotropin-releasing hormone (TRH): 5'-AACCTTACTCCTCCAGAGGTTCC
CTGACCCAGGCTTCCAGTTGTG-3'; tyrosin-hydroxylase (TH): 5'-TGGATACGAGAGGCATAGTTCCTGAGCTTGTCC TTGGCATCACTG-3'; tryptophan-hydroxylase 2 (TPH2): $5^{\prime}$ TTCGACTTCAGAACTTCTTCGTCGGGACCTCCTGGATTC GATATG-3': arginin-vasopressin (Avp): 5'-GGAGACACTG TCTCAGCTCCATGTCAGAGATGGCCCTCTT-3.

Oligonucleotides (10 pmol) were labeled with $\left[{ }^{35} \mathrm{~S}\right]$-dATP ( $1300 \mathrm{Ci} / \mathrm{mmol}, \mathrm{NEN}$, Vienna, Austria) by reaction with terminal deoxynucleotidyltransferase (Roche, Mannheim, Germany). Incubations with different probes were performed on series of matching sections from knockout and wild-type mice. Incubation lasted for $16-18 \mathrm{~h}\left(52^{\circ} \mathrm{C}\right)$. Sections were washed four times with $1-2 \times \operatorname{SSC}\left(58^{\circ} \mathrm{C}\right)$, dried, and exposed to Kodak MR films (Amersham, Buckinghamshire, UK) for 2 days or 1 week, depending on the intensity of the signal. Subsequently sections were dipped into radiation-sensitive emulsion (Kodak NTB, Integra Biosciences, Fernwald, Germany) and exposed for another 4-20 days. Matching sections from the same brain level of knockout and control mice were analyzed together, as described previously (Schwarzer et al, 1998).

For evaluation of in situ hybridization, digitized images of the areas of interest were acquired from photo emulsion dipped and superficially Nissl counter-stained brain slices at $200 \times$ magnification using a digital camera (Axiocam, Zeiss, Heidelberg, Germany) mounted onto a Zeiss Axiophot 2 microscope (Sainsbury et al, 2002). Silver-grain densities were evaluated by an experimentally blinded observer outlining single neurons and measuring percentage of area covered by silver grains (black grains in brightfield image, Image-J software). Percentage of silver-grain area compared to total area calculated for single neurons was averaged. Expression levels are given as mean percent of control.

Quantification of in situ hybridization signals on autoradiography films over distinct cell layers or entire small forebrain nuclei were performed as controls and yielded essentially the same alterations as measured from dipped sections (data not shown).

\section{Serum Analyses}

Animals were killed between 1200 and 1400 hours under deep $\mathrm{CO}_{2}$ anesthesia by decapitation. Trunk blood was captured and serum was stored at $-20^{\circ} \mathrm{C}$ until analyzed. Determination of corticosterone serum levels was done with a commercial radioimmunoassay (MP Biochemicals, Orangeburg, NY) according to manufacturer's suggestions. Each serum was analyzed in duplicates.

\section{Analgesia}

To disclose the influence of altered pain sensitivity in $\mathrm{dyn}^{(-1-)}$ mice, in some experiments animals were injected with meloxicam ( $2 \mathrm{mg} / \mathrm{kg} ; 30 \mathrm{~min}$ pretesting, i.p.). Meloxicam was chosen because it did neither display central nor locomotor effects at the dose applied (Engelhardt et al, 1996).

\section{Statistical Analysis}

For all comparisons of the two genotypes the Student's $t$-test was used. Comparison of more than two groups was done by one-way ANOVA, followed by Bonferroni post hoc test, 
applying GraphPad Prism 4.0 software. $P$-values of $<0.05$ were accepted as statistically significant. For the large number of comparisons in in situ hybridization analysis we applied the Holm's step-down method (Holm, 1979) to adjust for multiple testing. All comparisons regarding mRNA levels were included. All data are given as mean \pm SEM $(n)$.

\section{RESULTS}

\section{Physical Exam and Basic Behavior}

No obvious differences in fertility, body weight, sensory functions or fur, and whiskers condition were observed between wild-type and dyn ${ }^{(-)}$animals. Basic behavior was normal, lacking circling, excessive running, or jumping behavior. Noteworthy, in the empty cage, dyn ${ }^{(-)}$mice differed significantly in the number of freezing periods $(0.77 \pm 0.18 \quad(25) ; \quad p=0.0306) \quad$ compared to $\operatorname{dyn}^{(+/+)}$ $(1.47 \pm 0.29$ (17)) defined by complete immobility including the face (Karl et al, 2003)) and defecation frequency $\left(0.65 \pm 0.15\right.$ (17) in $\mathrm{dyn}^{(+/+)}$vs $0.27 \pm 0.09$ (25) in $\operatorname{dyn}^{(-1-)}$; $p=0.0252)$. In addition, in the hang wire test the duration spent on the wire was significantly longer in $\operatorname{dyn}^{(+/+)}\left(57.4 \pm 2.65\right.$ (17) vs $45.0 \pm 3.23$ (25 s) in dyn ${ }^{(-l-)}$, $p=0.0088$; Supplementary Figure S1A). Home-cage activity was indistinguishable between the two genotypes. Animals displayed normal behavior, showing highest activity in the first hours of the dark cycle and lowest activity in the light cycle (Supplementary Figure S1B). Arbitrary activity units counted over $48 \mathrm{~h}$ also did not differ $\left(\right.$ dyn $^{(+/+)} 25455 \pm 2250$ (8); $\left.\operatorname{dyn}^{(-l-)} 22424 \pm 2574(8)\right)$.

\section{Behavioral Testing}

To determine explorative behavior $14 \mathrm{dyn}^{(+/+)}$vs 14 $\operatorname{dyn}^{(--)}$mice were tested in the open field test (Figure 1a). Dyn ${ }^{(-l-)}$ mice showed significantly increased ambulation in both, the center and the intermediate zone of the open field. Overall motor activity was increased in $\operatorname{dyn}^{(-1-)}$ mice $(3.28 \pm 0.18 \mathrm{~m}$ in WT $v s 4.28 \pm 0.41 \mathrm{~m}$ in KO; $p=0.0377)$. This phenotype could be fully reversed by treatment with the specific KOR agonist U-50488H $(2.5 \mathrm{mg} /$ $\mathrm{kg} ; 2$ days and $24 \mathrm{~h}$ before testing; Figure $1 \mathrm{~b}$ ). A single injection of $2.5 \mathrm{mg} / \mathrm{kg} \mathrm{U}-5048830 \mathrm{~min}$ before testing did not attenuate the difference between the genotypes (Figure 1b). Blockade of KOR receptors by $3 \mathrm{nmol}$ GNTI $(20 \mathrm{~h})$ or $10 \mathrm{mg} /$ $\mathrm{kg}$ norBNI $(48 \mathrm{~h})$ in wild-type mice resulted in an open field behavior comparable to that of $\mathrm{dyn}^{(-)}$animals. Mice tested $1 \mathrm{~h}$ after norBNI were indistinguishable form salinetreated mice (Figure 1c).

In the elevated plus maze test, dyn ${ }^{(-l-)}$ mice spent over 3.5 -fold more time on the open arms $(2.13 \pm 0.57 \%$ (17) in dyn $^{(+l+)}$ vs $8.28 \pm 1.48 \%$ (25) in dyn ${ }^{(-I)} ; p=0.0020$; data represent $\%$ of total time spent in open arm) during twice as much visits $\left(19.4 \pm 2.76(17)\right.$ in dyn $^{(+l+)}$ vs $30.6 \pm 2.72(25)$ in dyn ${ }^{(-I-)} ; p=0.0085$; data represent $\%$ of total entries into open arm) compared to wild-type littermates (Figure 2a). In contrast, the number of closed arm entries did not differ significantly between genotypes, suggesting unchanged locomotor activity. Consistent with our observations in the open field, 2-day treatment with the KOR-specific agonist U-50488H reversed this phenotype (Figure $2 \mathrm{~b}$ ). The phenotype of $\mathrm{dyn}^{(-/-)}$mice was also mimicked by longlasting blockade of KOR receptors applying GNTI or norBNI in wild-type mice (Figure 2c).

At both illumination levels tested in the light-dark test, 150 and 400 lux, dyn ${ }^{(-l-)}$ mice spent significantly more time in the lit area than dyn ${ }^{(+)}(160 \pm 16.8$ (12) vs $288 \pm 28.1 \mathrm{~s}$ (14) and $113 \pm 13.0$ (19) vs $195 \pm 25.3 \mathrm{~s}$ (16), respectively; Figure 3)) and traveled a longer distance than wild-type littermates $(0.9 \pm 0.11 \mathrm{~m}$ (12) vs $2.1 \pm 0.21 \mathrm{~m}$ (14) and $0.8 \pm 0.13 \mathrm{~m}$ (19) vs $1.3 \pm 0.17 \mathrm{~m}$ (16), respectively). Interestingly, the number of entries into the lit compartment differed only at 400 lux light intensity (13.2 \pm 1.8 (19) $\operatorname{dyn}^{(+/+)}$vs $21.1 \pm 2.75$ (16) dyn ${ }^{(-l-)}$; Figure 3).

In the flinch test dyn ${ }^{(-)}$mice responded later to the electrical footshocks. Flinch response was detected at about $20 \%$ higher amperage $(0.23 \pm 0.012 \mathrm{~mA}$ (11) vs $0.28 \pm 0.018 \mathrm{~mA}(11) ; p=0.0461$ in dyn $^{(+/+)}$and $\operatorname{dyn}^{(-l-)}$, respectively) jump/run $\quad(0.27 \pm 0.024 \mathrm{~mA} \quad$ (11) $v s$ $0.35 \pm 0.035 \mathrm{~mA}(11) ; p=0.0676$ in dyn $^{(+/+)}$and dyn ${ }^{(-l-)}$, respectively), and scream responses $(0.34 \pm 0.037 \mathrm{~mA}$ (11) vs $0.46 \pm 0.027 \mathrm{~mA}(11) ; p=0.0172$ in dyn $^{(+/+)}$and dyn ${ }^{(-l-)}$, respectively) at approximately $30 \%$ higher amperage as in dyn $^{(+/+)}$controls.

Significant differences were also observed between the two genotypes in depression-like behavior and stressresponse-related tests. In the repeated modified Porsolt swim test, both groups displayed an increase of immobility from initially 115 to finally $180 \mathrm{~s}$ in the last test (Figure 4a). However, in dyn ${ }^{(-I-)}$ mice this increase occurred earlier, resulting in significant differences in immobility as well as active struggling in the third test (Figure 4a). In unstressed animals, immobility in the tail suspension test was increased in dyn ${ }^{(-l)}$ mice $(131 \pm 14.3 \mathrm{~s}(11) ; p=0.0269$; Figure $4 \mathrm{~b})$ as compared to wild-type animals $(86.7 \pm 12.3 \mathrm{~s}$ (14)). This was accompanied by a reduced latency to the first immobility phase $\left(67.7 \pm 7.90 \mathrm{~s}\right.$ (11) in $\mathrm{dyn}^{(-1-)} v \mathrm{~s}$ $101 \pm 10.2 \mathrm{~s}$ (14) in dyn ${ }^{(+/+)}$mice; $p=0.0222$ ). This difference was completely abolished in mice tested 1 day after the repeated forced swim test $(135 \pm 8.54 \mathrm{~s}$ (9) for $\operatorname{dyn}^{(-l-)} ; 132 \pm 13.7 \mathrm{~s}$ (9) for WT). Importantly, dyn ${ }^{(-l-)}$ mice did not respond with any increase in immobility on the prestressing. Prodynorphin deficient mice display testdependent mild hyperalgesia (Wang et al, 2001), but respond later to electrical footshocks (see above). In addition, they lack stress-induced analgesia (McLaughlin et al, 2003). Hyperalgesia may influence the behavior of mice in the tail suspension test through pain induced by hanging on the tail tip. Therefore, we repeated this test $40 \mathrm{~min}$ after i.p. injection of $2 \mathrm{mg} / \mathrm{kg}$ meloxicam. Under these conditions, $\mathrm{dyn}^{(-l-)}$ mice $(117 \pm 10.2 \mathrm{~s}$ (12); $p=0.0410 v s$ wild type) displayed significantly less immobility than $\operatorname{dyn}^{(+/+)}$mice (148 $\pm 10.0 \mathrm{~s}$ (14); Figure $4 \mathrm{~b}$ ).

Basal body temperature and stress-induced hyperthermia induced by insertion of an anal probe did not differ significantly between non prestressed animals of the two genotypes (Figure 4c).

\section{Central Alterations in Response to Prodynorphin Gene Deletion}

To clarify the role of dynorphin peptides in the central regulation of anxiety, we investigated changes in expression 


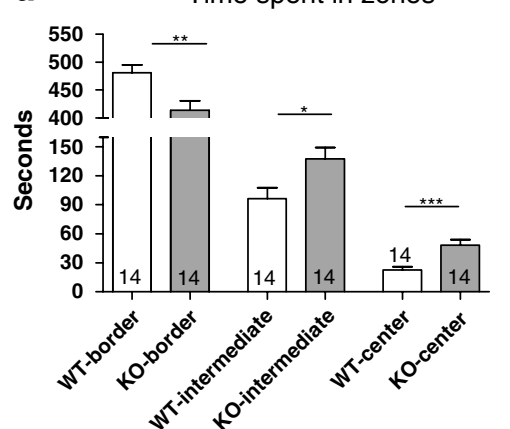

b

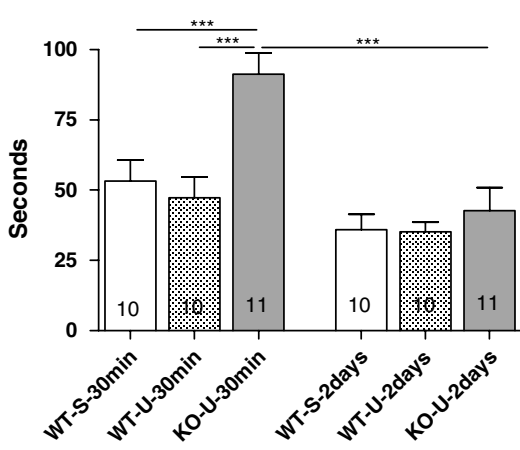

c

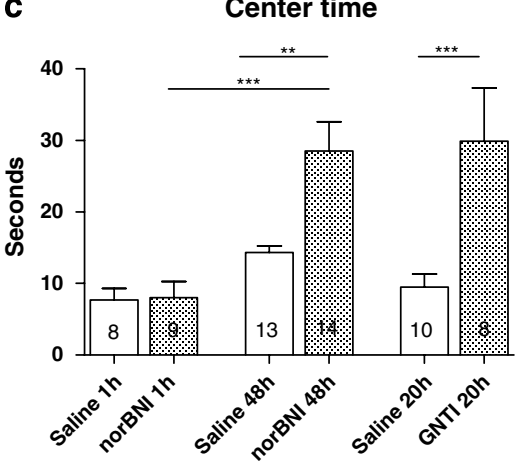

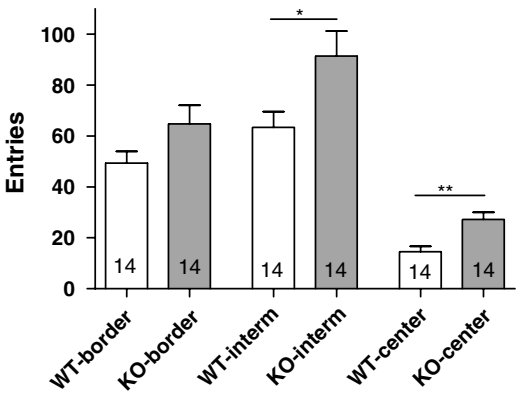

Center entries

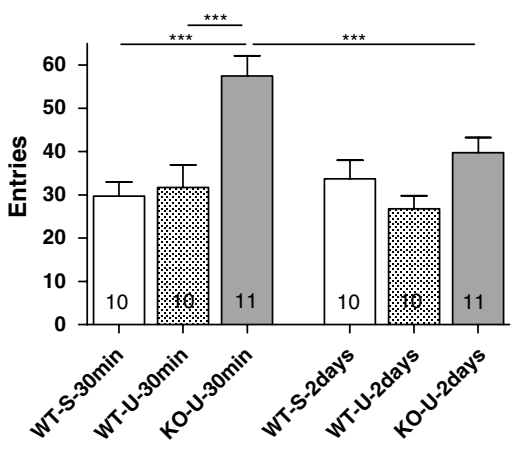

Center entries

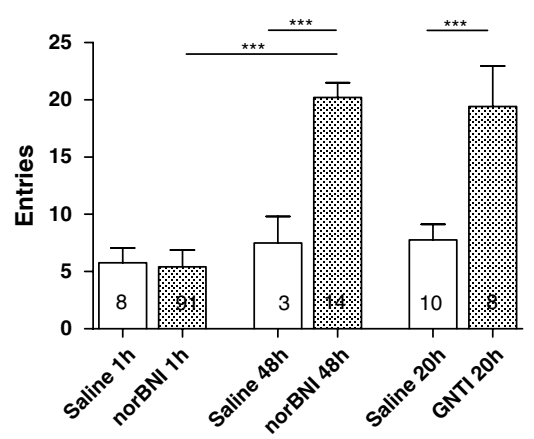

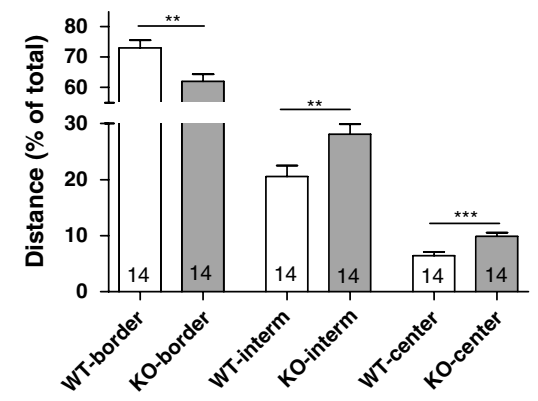

$\left.\begin{array}{l}90 \\ 80\end{array}\right]$ T

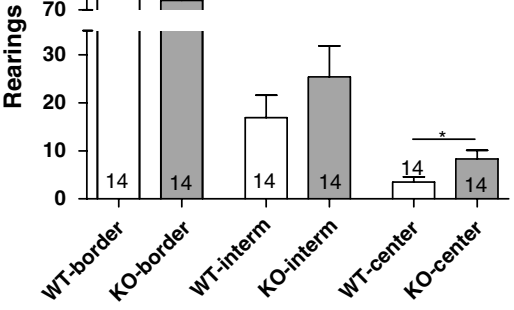

Center rearings

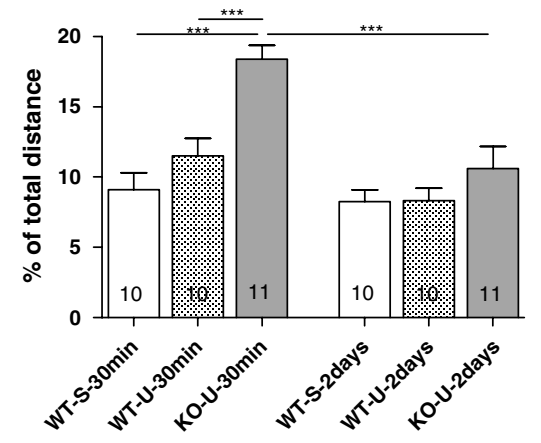

Center distance

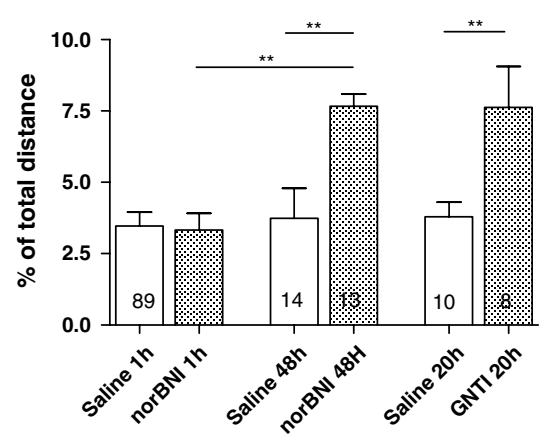

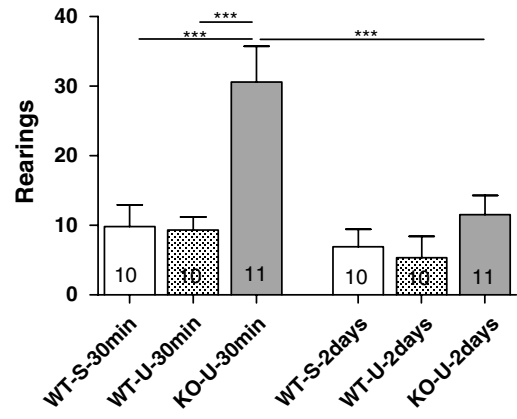

Center rearings

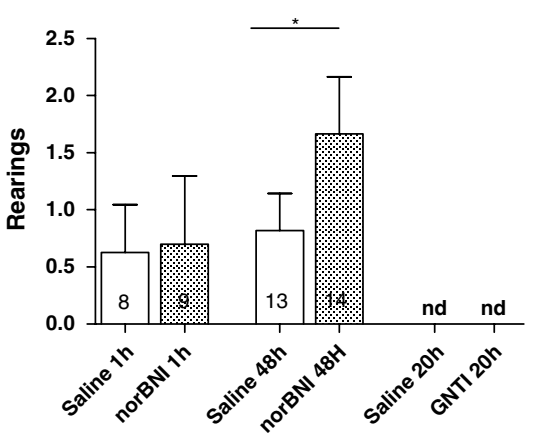

Figure I Ambulation in the open field was assessed over 10 min for dyn ${ }^{(+/+)}$and dyn ${ }^{(-/-)}$mice. Dyn ${ }^{(-/-)}$mice more often entered the intermediate and central zone and spent significantly more time and traveled longer distances in these compartments. In contrast, dyn ${ }^{+}$mice preferentially remained in the border zone (a). Intraperitoneal injection of the KOR-specific agonist U-50488H did not affect

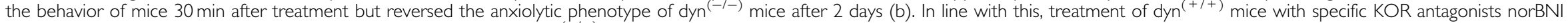
$\left(10 \mathrm{mg} / \mathrm{kg}\right.$, i.p.) and GNTI ( $3 \mathrm{nmol}$, i.c.) mimicked the phenotype of dyn ${ }^{(-1-)}$ mice after 48 and $20 \mathrm{~h}$, respectively (c).

* $p<0.05 ; * *$ * $<0.01 ; * * * p<0.001$ vs respective control. 
a

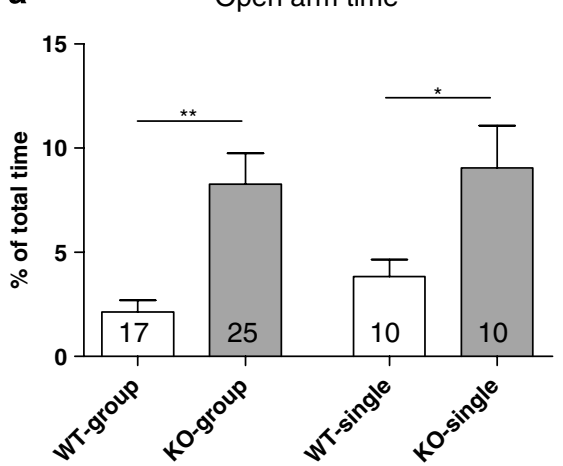

b

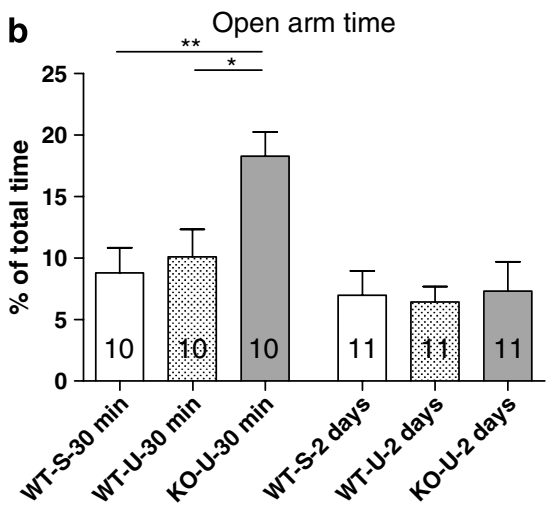

c

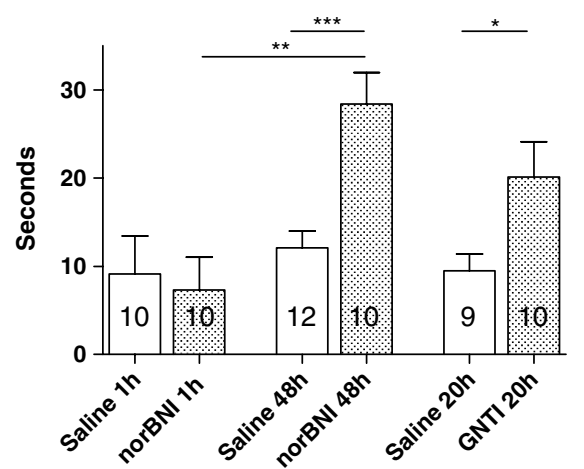

Open arm entries
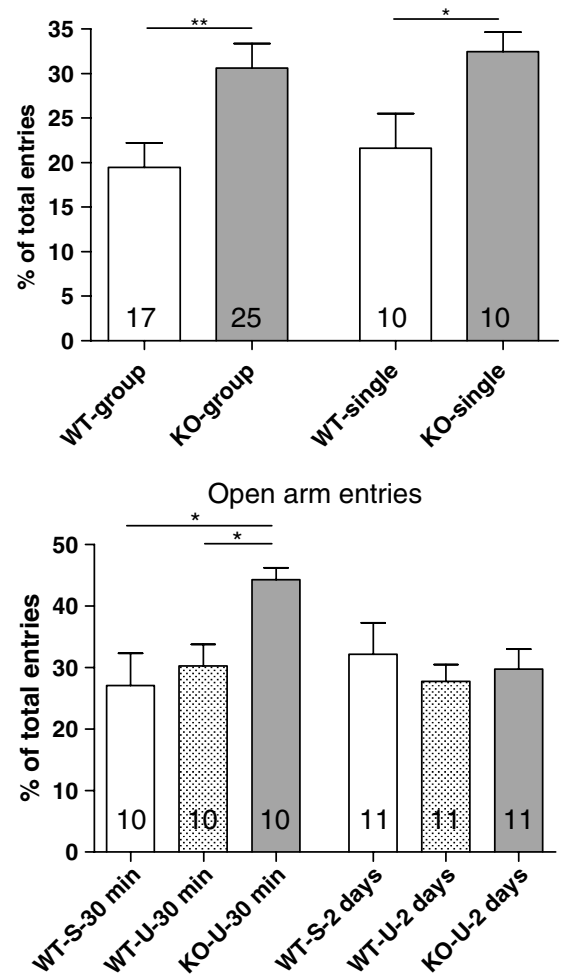

Open arm entries

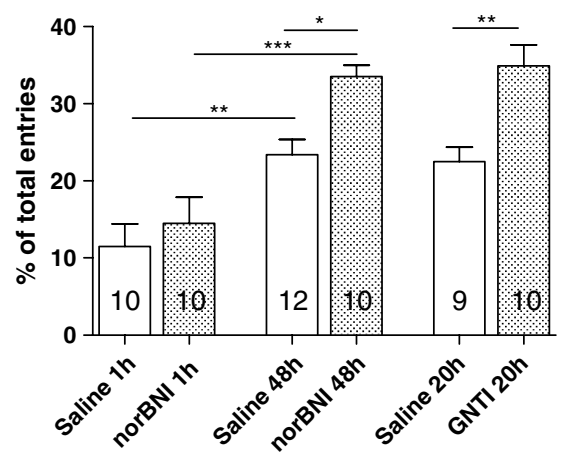

Closed arm entries

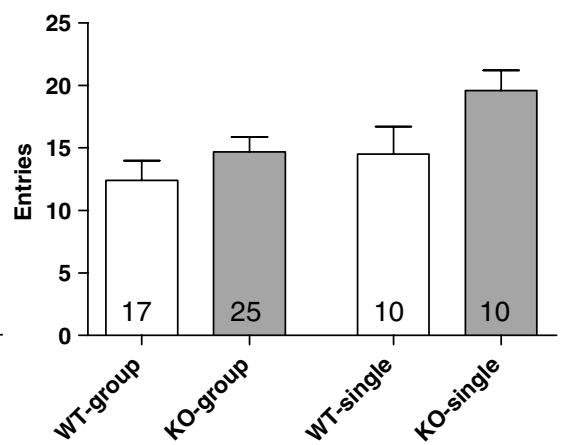

Closed arm entries

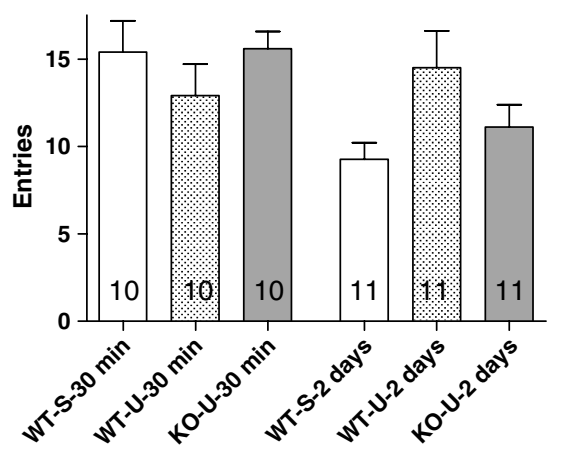

Closed arm entries

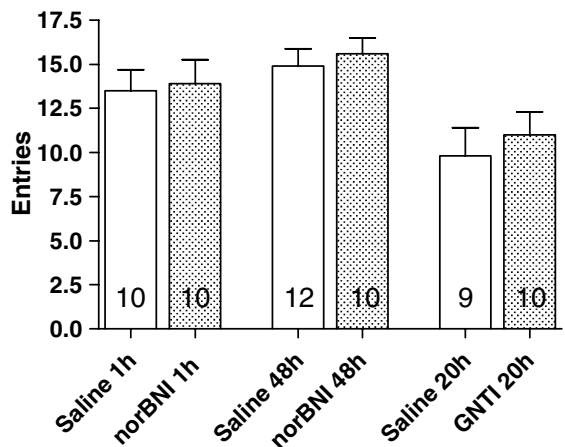

Figure 2 Explorative behavior was tested in group- and single-housed mice (a). Independent of housing conditions, dyn ${ }^{(-l-)}$ mice more often entered the open arms and spent significantly more time on the open arms than dyn ${ }^{(+/+)}$mice. No differences were observed in the number of closed arm entries, suggesting unchanged motor activity (a). Intraperitoneal injection of the KOR-specific agonist U-50488H did not affect the behavior of mice 30 min after treatment but reversed the anxiolytic phenotype of dyn ${ }^{(-1-)}$ mice after 2 days (b). In line with this, treatment of dyn ${ }^{(+/+)}$mice with specific KOR antagonists norBNI ( $10 \mathrm{mg} / \mathrm{kg}$, i.p.) and GNTI (3 nmol, i.c.) mimicked the phenotype of dyn ${ }^{(-)}$mice after 48 and $20 \mathrm{~h}$, respectively (c).

$* p<0.05$; ** $p<0.0$ I; **** $p<0.00$ I vs respective control.

levels of neurotransmitters known to involved in anxiety and emotional control (Table 1). Thus, in the central amygdala, CART and CRH mRNAs were decreased in dyn $^{(-)}$mice (by 23 and $33 \%$, respectively), whereas neurokinin $\mathrm{B}$ mRNA was increased by $15 \%$. In the paraventricular nucleus of the hypothalamus $\mathrm{CRH}$ and TRH, mRNAs were decreased by 27 and $24 \%$ (Table 1), respectively. In contrast PPTA mRNA was increased by $35 \%$. No changes of TRH expression were observed in the lateral hypothalamic area. NPY and CART mRNAs were increased in the medial amygdala of $\operatorname{dyn}^{(-I-)}$ mice by 45 and $19 \%$ (Table 1), respectively. In this nucleus PPTA and chromogranin B mRNAs were decreased by about $13 \%$. In the arcuate nucleus, AgRP and NPY mRNAs were decreased (by 38 and 26\%, respectively), in parallel, CART and POMC mRNAs were increased by 18 (nonsignificant) and $21 \%$ (Table 1), respectively. In this nucleus, a strong increase (by 77\%) of NKB mRNA expression was measured. Chromogranin B mRNA was unchanged in hypothalamic nuclei, but somewhat reduced in the medial amygdala. Although most minor changes lost statistical significance when correction for multiple comparisons was performed, the functionally important changes of NPY and CRH in the amygdala and paraventricular nucleus of the hypothalamus were solid (shaded fields in Table 1).

Noteworthy, orexin mRNA, which is colocalized with dynorphin mRNA in neurons of the lateral hypothalamic area was unchanged (Table 1). Significant changes in the 
a Open area time

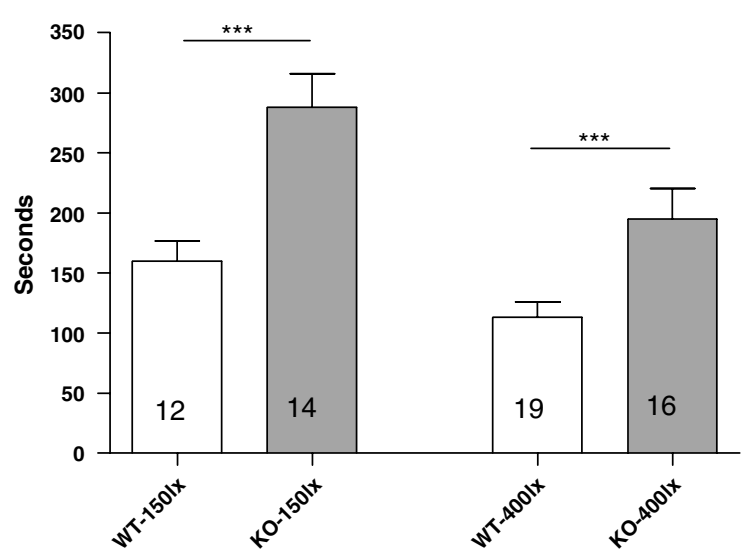

b

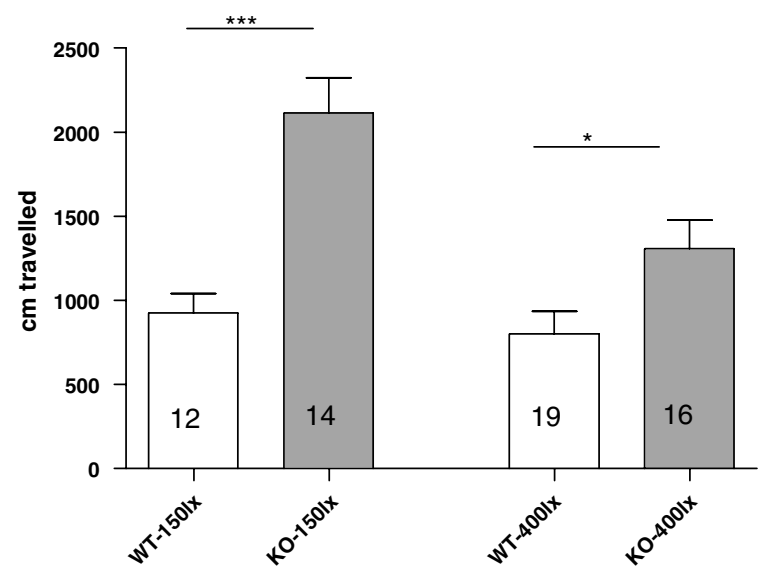

C

Open area entries

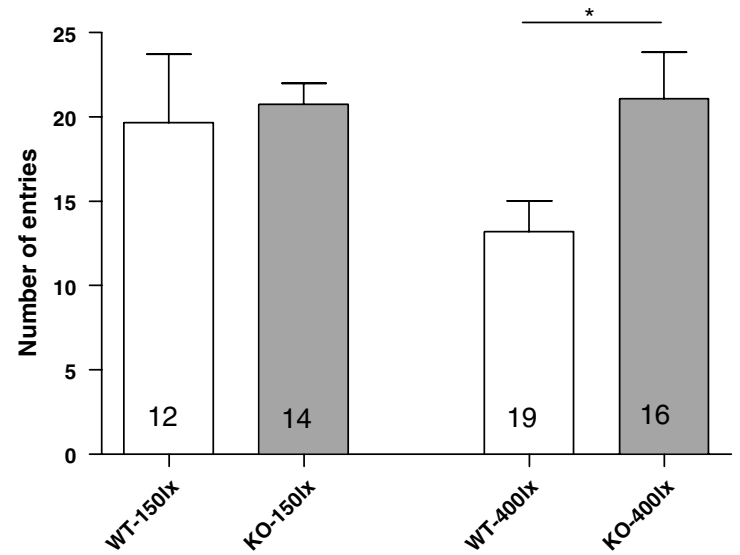

Figure 3 At 150 and 400 lux illumination, dy ${ }^{(+/+)}$mice displayed less explorative behavior in the lit area, as reflected by lower time (a) and lower distance (b) measured in the open compartment. Interestingly, open area entries differed only at the higher aversive 400 lux (c).

* $p<0.05$; ***** $p<0.0$ I vs respective control.

mRNA expression were neither detected for $\mathrm{TH}$ in the locus coeruleus nor for TPH2 in the dorsal raphe nucleus (Table 1).

Interestingly, the reduction of $\mathrm{CRH}$ mRNA in the paraventricular nucleus and the central amygdala was also observed in dyn ${ }^{(+/+)}$animals injected with $10 \mathrm{mg} / \mathrm{kg}$ norBNI $48 \mathrm{~h}$ before analysis (Figure 5).

\section{Peripheral Alterations in Response to Prodynorphin Gene Deletion}

To investigate how the ablation of prodynorphin could influence anxiety-related behaviors, we measured key parameters in the serum of these mice. Consistent with the reduced anxiety in dyn ${ }^{(-l-)}$ mice serum corticosterone levels were significantly reduced $(74.4 \pm 13.8 \mathrm{ng} / \mathrm{ml}$ (6); $p<0.05)$ as compared to dyn ${ }^{(+/+)}$mice $(125 \pm 7.9 \mathrm{ng} / \mathrm{ml}$ (5)). Similarly, wild-type mice treated with $10 \mathrm{mg} / \mathrm{kg}$ norBNI $48 \mathrm{~h}$ before analysis showed attenuated corticosterone levels $(80.3 \pm 27.6 \mathrm{ng} / \mathrm{ml}(6))$. Stress-induced (i.p. saline injection $1 \mathrm{~h}$ before testing) increases in corticosterone serum levels of wild-type mice $(226 \pm 16.3 \mathrm{ng} / \mathrm{ml}$ (6) were significantly attenuated in $\mathrm{dyn}^{(-)}$mice $(167 \pm 4.6 \mathrm{ng} / \mathrm{ml}(7) ; p<0.05$ vs $\operatorname{dyn}^{(+/+)}$saline; ANOVA with Dunnett's post hoc test; Figure $4 d$ ).

\section{DISCUSSION}

This study demonstrates a clear-cut anxiogenic role of prodynorphin-derived peptides as $\mathrm{dyn}^{(-/-)}$mice display markedly increased explorative behavior in three independent anxiety tests. In contrast, we observed longer duration of immobility in the tail suspension test and a faster increase in immobility in the repeated forced swim test. This phenotype is accompanied by marked alterations of the expression levels of neuropeptides (CRH and NPY) known to play a critical role in the regulation of emotionality in key areas of the amygdala and the hypothalamus. Consistent with this serum levels of corticosterone are also decreased in these animals (Shepard et al, 2000). Importantly, the increased exploratory behavior could be reversed by treatment with the specific KOR agonist U-50488. Blockade of KOR in wild-type mice by applying the specific antagonists norBNI and GNTI revealed an increase in exploratory behavior and a reduction of corticosterone serum levels. The delay in both, behavioral and corticosterone level response to KOR blockade in wild type or KOR stimulation in $\mathrm{dyn}^{(-1-)}$ mice suggests an indirect effect of prodynorphin-derived peptides on anxiety control. Our data partially contradict a recently published study, reporting inconsistent results of dynorphin knockout mice from different anxiety tests (Bilkei-Gorzo et al, 2008). In this study, the zero-maze and the startle-response test suggested anxiolytic effects of endogenous dynorphins, although no effect was seen in the light-dark test at very high illumination (1000 lux). This is contradicted by their finding of decreased stress-induced hyperthermia, which would indicate an anxiogenic effect of endogenous dynorphins. However, decreased stress-induced hyperthermia was accompanied by increased basal body temperature, which was not reported from other strains of $\mathrm{dyn}^{(-/-)}$mice. Importantly, they report differences in hormonal stress response (amplitude and duration) in $\mathrm{dyn}^{(-l-)}$ mice $v s$ controls. Therefore, the discrepancies between their and our data may be based beside differences of the genetic background also on different housing conditions leading to differences in basal stress levels. In any case, we observed consistent data from three independent tests, which were reproducible with pharmacological approaches and are 

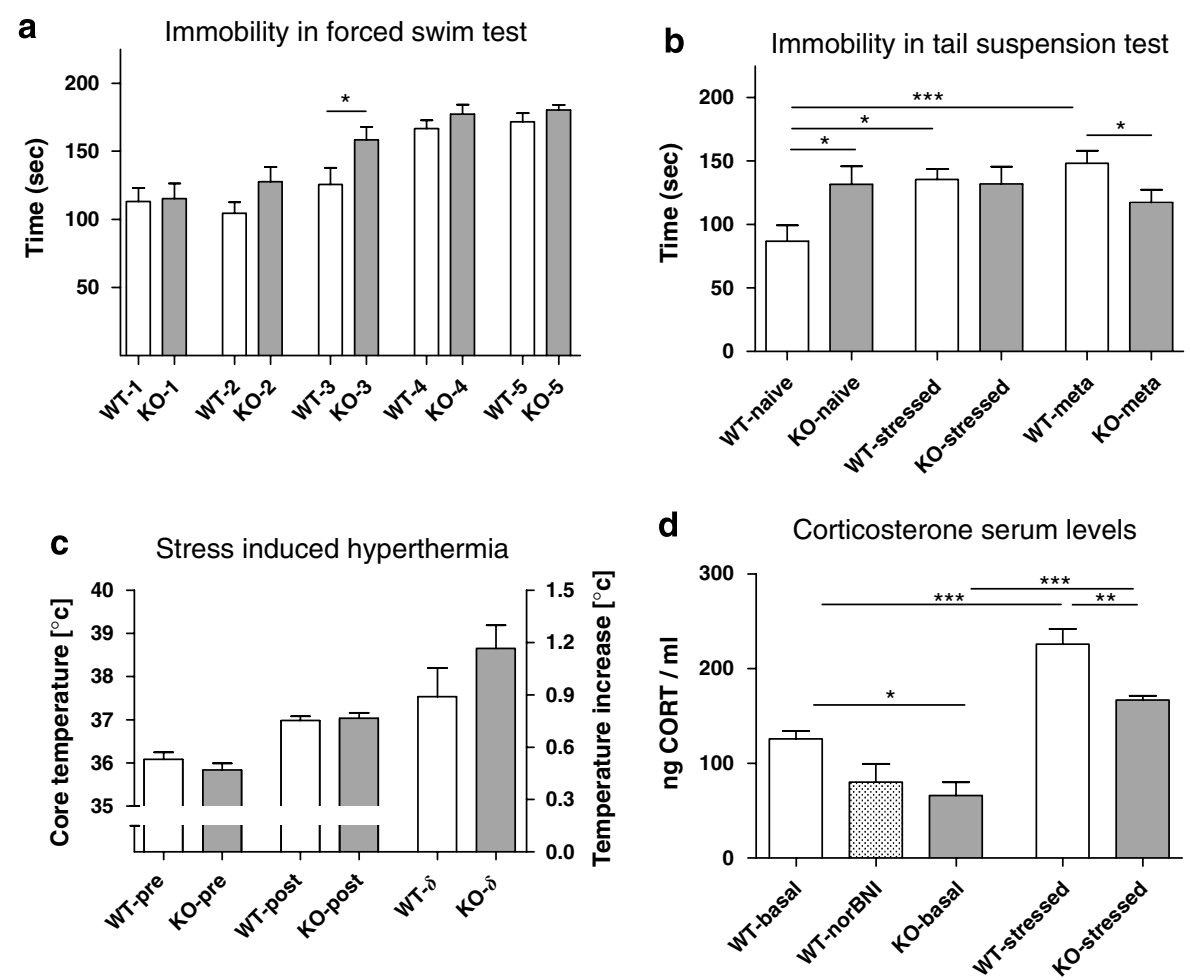

Figure 4 Time spent immobile did not differ between $\mathrm{dyn}^{(+/+)}$and dyn ${ }^{(-/-)}$mice in the first and last trial of the repeated forced swim test. However immobility times increased earlier in dyn ${ }^{(-)}$mice, reaching statistical significance at trial 3 (a). Non prestressed dyn ${ }^{(+/+)}$mice displayed less immobility in the tail suspension test than $d y n^{(-l-)}$ mice. Interestingly, in prestressed animals, no difference was observed, which was due to increased immobility in dyn $^{(+1+)}$ mice (b). Immobility was reduced in dyn ${ }^{(-)}$, but not in dyn ${ }^{(+/+)}$mice under meloxicam anesthesia (b). This is in line with reports on mild hyperalgesia and lack of stress-induced analgesia in dyn ${ }^{(-)}$mice. No differences between the genotypes were observed in stress-induced hyperthermia (c). Basal corticosterone serum levels were reduced in both $\mathrm{dyn}^{(+/+)}$mice pretreated with $10 \mathrm{mg} / \mathrm{kg}^{\mathrm{k}}$ norBNl and dyn ${ }^{(-/-)}$animals. Stress-induced corticosterone levels were also augmented in dyn ${ }^{(-/-)}$mice (d).

$* p<0.05$; $* * 0.0$ I; *** $p<0.00$ I vs respective control.

supported by neurochemical and hormonal changes observed in dyn ${ }^{(-)}$mice.

In line with reports on other prodynorphin-deficient mouse lines (Sharifi et al, 2001), no obvious influence of the deletion on basal behavior or physiological parameters (ie home-cage activity, fertility, body weight, and core temperature) was observed. However, we measured a significantly reduced holding time in the wire-hang test. This stands in contradiction to the performance on the rotarod and the increased activity in the open field test. Noteworthy, during the wirehang test, the animals did not loose hold, but actively explored the distance to the ground and voluntarily jumped down. Thus, the reduced holding time might rather reflect the anxiolytic phenotype than reduced physical strength. This is also supported by the reduced number of freezing events and reduced defecation in the empty cage observation. On the other hand, an effect of prodynorphin deficiency on motor performance cannot be excluded as dynorphin is involved in the regulation of dopamine release in rat striatum (Schoffelmeer et al, 1997). However, this did not translate into changed home-cage activity.

Regulation of anxiety behavior involves several neurotransmitter systems. Beside the classical transmitters serotonin (Wise et al, 1970; Westenberg et al, 1987; Graeff, 2002) and noradrenalin (Vlachakis et al, 1974; Brunello et al, 2003), also several neuropeptides were proposed as modifiers of anxiety-related behavior.
The minor effects of short-term treatment of $\mathrm{dyn}^{(-1-)}$ mice with KOR agonists or of wild-type mice with KOR antagonists argue against a direct interaction with anxiety control. This is in line with reports on functions of dynorphin agonists and antagonists in the control to anxiety (Kuzmin et al, 2006; Knoll et al, 2007), but may also be due to strong influences of test paradigms and social status of mice (Kudryavtseva et al, 2004). On the basis of our findings of delayed effects on anxiety-related behavior induced by KOR agonist treatment of $\mathrm{dyn}^{(-)}$mice and KOR antagonists treatment in dyn ${ }^{(+)}$mice, we suggest an indirect modulation of anxiety control circuits in dyn ${ }^{(-l-)}$ mice. This is supported by neurochemistry in dyn ${ }^{(-l-)}$ mice detecting specific alterations in transmitter systems known to be involved in emotional control. Interestingly, $\operatorname{dyn}^{(-1-)}$ mice show no difference in the expression of tyrosine- or tryptophan-hydroxylase mRNA, suggesting unchanged levels of serotonin and catecholamines. However, several neuropeptide systems within amygdalar and hypothalamic nuclei displayed adaptations that may be of relevance for the observed anxiolytic phenotype. The key features are increased NPY expression in the basolateral amygdala and concomitant reduction in CRH expression in the central amygdala and the PVN, which could be reproduced in wildtype mice by a single injection of $10 \mathrm{mg} / \mathrm{kg}$ norBNI $48 \mathrm{~h}$ before testing. These changes may reflect alterations in the regulatory circuit of NPY in the basolateral amygdala 
Table I Alterations in Neuropeptide mRNA Levels in Prodynorpin KO Mice

\begin{tabular}{|c|c|c|c|c|}
\hline Area & Nucleus & mRNA & WT & KO \\
\hline \multirow[t]{9}{*}{ Amygdala } & \multirow[t]{4}{*}{ Central } & CART & $100 \pm 5.14(6)$ & $76.8 \pm 5.99(6)^{*}$ \\
\hline & & $\mathrm{CRH}$ & $100 \pm 4.06(6)$ & $66.5 \pm 5.11(6)$ ***** \\
\hline & & NKB & $100 \pm 2.47(6)$ & $115 \pm 2.96(6)^{* * *}$ \\
\hline & & PPTA & $|00 \pm 3.5|$ & ||$| \pm 5.5|(6)$ \\
\hline & \multirow{4}{*}{ Medial } & CART & $100 \pm 4.09$ & $119 \pm 6.24(6)^{*}$ \\
\hline & & $\mathrm{CgB}$ & $100 \pm 3.31$ & $86.8 \pm 3.51$ (6)* \\
\hline & & NPY & $100 \pm 3.04$ & $145 \pm 5.89(6)$ **** \\
\hline & & PPTA & $100 \pm 3.5 \mid(6)$ & $86.9 \pm 4.38(6)^{*}$ \\
\hline & Basolateral & NPY & $|00 \pm 6.7|$ & $133 \pm 5.45(5)$ *** \\
\hline \multirow[t]{13}{*}{ Hypothalamus } & \multirow[t]{4}{*}{ Paraventricular } & $\mathrm{CgB}$ & $100 \pm 4.45$ & $100 \pm 3.96(6)$ \\
\hline & & $\mathrm{CRH}$ & $100 \pm 6.62(9)$ & $73.0 \pm 4.79(10) * *$ \\
\hline & & PPTA & $100 \pm 3.84$ & $135 \pm 7.30(6)^{* * *}$ \\
\hline & & $\mathrm{TRH}$ & $100 \pm 2.54$ & $76.2 \pm 2.41(5)$ **** \\
\hline & \multirow[t]{6}{*}{ Arcuate } & $\mathrm{AgRP}$ & $100 \pm 8.35$ & $61.7 \pm 6.82(5)$ **** \\
\hline & & CART & $100 \pm 3.99$ & $118 \pm 7.33$ (5) \\
\hline & & $\mathrm{CgB}$ & $100 \pm 8.98$ & $97.5 \pm 8.12(5)$ \\
\hline & & NKB & $100 \pm 3.32(6)$ & $177 \pm 1.43(6) * * *$ \\
\hline & & NPY & $100 \pm 3.97(6)$ & $73.9 \pm 3.17(6)$ **** \\
\hline & & POMC & $100 \pm 2.18$ & $|2| \pm 5.20(6)$ *** \\
\hline & \multirow[t]{3}{*}{ Lateral area } & Orexin & $100 \pm 1.7 \mid(6)$ & $98.0 \pm 4.25(6)$ \\
\hline & & NKB & $100 \pm 6.77(6)$ & $128 \pm 6.84(6)^{*}$ \\
\hline & & TRH & $100 \pm 6.70$ & $99.0 \pm 4.98$ \\
\hline Mesencephalon & $\begin{array}{l}\text { Dorsal raphe } \\
\text { nucleus }\end{array}$ & $\mathrm{TPH} 2$ & $100 \pm 6.06(7)$ & $110 \pm 5.65$ \\
\hline Brain stem & Locus coeruleus & $\mathrm{TH}$ & $100 \pm 3.74(7)$ & $95.5 \pm 3.60(6)$ \\
\hline
\end{tabular}

Data are given as percent of control and represent mean \pm SEM (number of animals).

* $p<0.05$; *** $p<0.0$ I; **** $p<0.00$ I vs respective control obtained by Student's t-test.

Gray shading indicates statistically significant differences confirmed after adjustment for multiple testing applying the Holm's step-down method. suppressing CRH expression in the central nucleus (Heilig et al, 1994; Sajdyk et al, 2004). Increasing evidence shows a crucial role of NPY and Y-receptors in anxiety-related behavior (for review see (Kask et al, 2002)). Thus, injection of NPY into the amygdala was shown to be anxiolytic. Y1receptors were proposed to mediate these anxiolytic effects (Wahlestedt et al, 1993). This was recently confirmed in Y1receptors-deficient mice (Karlsson et al, 2008). In addition, NPY is seen as the major counterpart of CRH, mediating mostly opposing effects and thereby balancing the emotional state (for reviews see (Heilig et al, 1994; Sajdyk et al, 2004)). Furthermore, intraventricular injection of CRH or overexpression of CRH is anxiogenic in mice (Stenzel-Poore et al, 1996) and inactivation of CRH receptor 1 reduces anxiety (Smith et al, 1998; Timpl et al, 1998), whereas deletion of $\mathrm{CRH}$ receptor 2 is anxiogenic (Bale et al, 2000; Coste et al, 2000; Kishimoto et al, 2000).

Interesting to note is also the moderate decrease in expression of PPTA mRNA, the precursor of substance $\mathrm{P}$, in the medial amygdala. In recent years, increased efflux of substance $\mathrm{P}$ under stressful conditions was shown in the amygdala (Ebner et al, 2004). Mainly acting via NK1 receptors, substance $\mathrm{P}$ produces anxiogenic effects when injected into the dorsal periaqueductal gray, lateral septum, or medial amygdala (Aguiar and Brandao, 1996; Gavioli et al, 1999; Ebner et al, 2004). Interestingly, NK1 receptor activation can increase the expression of the anxiogenic CRH receptor 1 , as shown in cell culture (Hamke et al, 2006). In addition, in dyn ${ }^{(-l-)}$ mice, CART mRNA was reduced in the central, but increased in the medial amygdala and in the arcuate nucleus of hypothalamus. Although CART was mostly investigated in relation to feeding behavior, there is some evidence that CART is also involved in the regulation of anxiety. Thus, Kask et al (2000) demonstrated dose-dependent anxiogenic effects of icv-injected CART in the elevated plus maze. However, the mechanism by which CART elicits its anxiogenic effects remains unknown (Stanek, 2006). On the other hand the decreases in PPTA and CART expression are moderate compared to the alterations in CRH expression and may be compensated by concomitant increases in other nuclei. Thus, a major role of substance

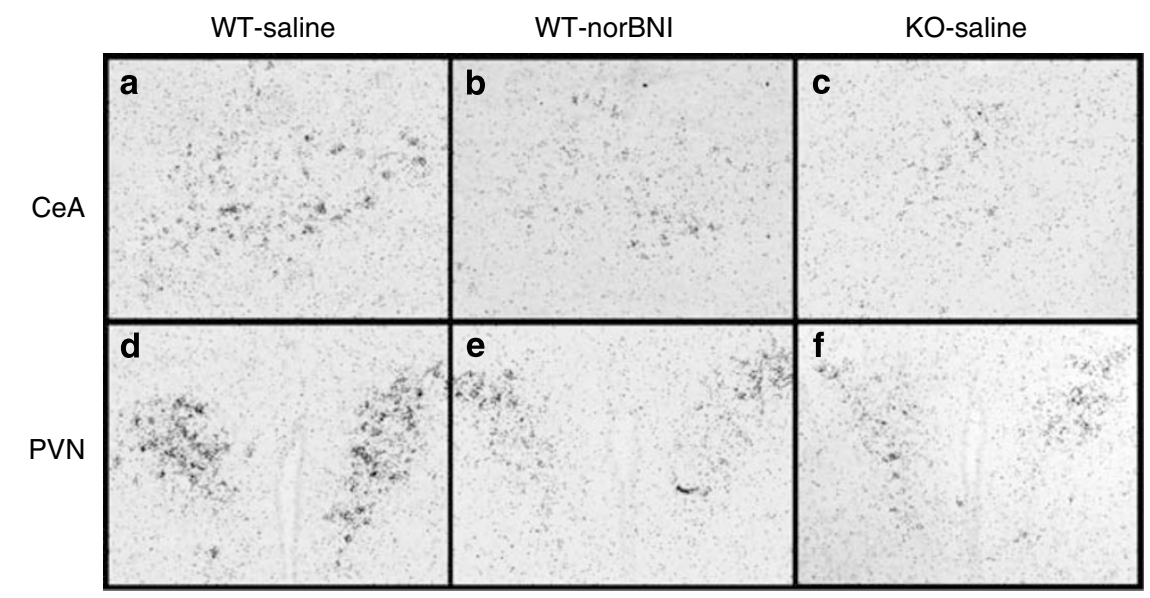

Figure 5 High-resolution in situ hybridization for CRH mRNA in the central amygdala (upper panel) and the paraventricular nucleus (lower panel). Photomicrographs obtained from $20 \mu \mathrm{m}$ sections are depicted for wild-type mice $48 \mathrm{~h}$ after saline (a, d) or $10 \mathrm{mg} / \mathrm{kg}$ norBNl (b, e) injection and salineinjected dyn ${ }^{(-l-)}$ mice (c, f). Note the marked drop in signal after norBNl treatment, which is comparable to the labeling seen in dyn ${ }^{(-l-)}$ animals. 
$\mathrm{P}$ or CART in the anxiolytic phenotype of $\mathrm{dyn}^{(-)}$mice is rather unlikely.

Interestingly, dyn $^{(-/-)}$mice display a prolonged period of elevated corticosterone plasma levels after the zeromaze test, which causes mild stress-responses in mice. Therefore, a delayed termination of the stress-response was proposed in these mice (Bilkei-Gorzo et al, 2008). This supports our findings in the repeated forced swim test, where dyn ${ }^{(-l-)}$ mice show a faster increase in immobility and a decrease of struggling in the second and third repeat on day 2. At first glance, our data contradict the findings of McLaughlin et al (2003) who did not find increasing immobility. However, they used $30^{\circ} \mathrm{C}$ warm water and a test interval of 7-12 min on day 2 . In contrast, we used $23-25^{\circ} \mathrm{C}$ water and an interval between trials of about $2 \mathrm{~h}$. Lower water temperature reduces floating behavior of mice in the forced swim test (Bachli et al, 2008). The increased test interval may influence the progression of immobility especially if one group of mice shows delayed stress termination, as reported for the $\mathrm{dyn}^{(-)}$mice (BilkeiGorzo et al, 2008). Noteworthy, our final immobility times are very similar to those observed by McLaughlin et al (2003).

In line with partially increased depressive-like behavior in the forced swim test, we also observed increased immobility in the tail-suspension test in naive $\operatorname{dyn}^{(-)}$animals. However, this difference was abolished in prestressed mice. Interestingly, this was due to increased immobility in wildtype mice, whereas there was no difference in immobility between naive and stressed dyn ${ }^{(-)}$mice. One potential explanation could be the mild hyperalgesia, which was reported for $\mathrm{dyn}^{(--)}$mice (Wang et al, 2001). In addition, dyn $^{(-I-)}$ mice lack stress-induced analgesia (McLaughlin et al, 2003). Indeed, we could reduce immobility in dyn ${ }^{(-1-)}$, but not wild-type mice by pretreatment with the nonsteroidal analgesic meloxicam. Noteworthy, we also observed higher thresholds to electrical footshocks in $\operatorname{dyn}^{(-I-)}$ mice. However, this might reflect more the anxiolytic than a hypoalgesic phenotype.

\section{CONCLUSIONS}

Our data provide clear evidence that prodynorphin-derived peptides acting on KOR are important in anxiety control. KOR signaling modulates the neurochemistry of brain nuclei involved in control of emotionality through the regulation of the expression of other main players in anxiety, CRH, and NPY.

\section{ACKNOWLEDGEMENTS}

We thank Cornelia Aigner and Inge Kapeller for excellent technical assistance. We also thank Dr Gerald Obermair for statistical advice.

\section{DISCLOSURE/CONFLICT OF INTEREST}

This work was supported by the Austrian Science Fund grants P18471-B5 and P20107-B5 to Christoph Schwarzer. Other authors have nothing to disclose.

\section{REFERENCES}

Aguiar MS, Brandao ML (1996). Effects of microinjections of the neuropeptide substance $\mathrm{P}$ in the dorsal periaqueductal gray on the behaviour of rats in the plus-maze test. Physiol Behav 60: 1183-1186.

Bachli H, Steiner MA, Habersetzer U, Wotjak CT (2008). Increased water temperature renders single-housed C57BL/6J mice susceptible to antidepressant treatment in the forced swim test. Behav Brain Res 187: 67-71.

Bale TL, Contarino A, Smith GW, Chan R, Gold LH, Sawchenko PE et al (2000). Mice deficient for corticotropin-releasing hormone receptor-2 display anxiety-like behaviour and are hypersensitive to stress. Nat Genet 24: 410-414.

Bilkei-Gorzo A, Racz I, Michel K, Mauer D, Zimmer A, Klingmuller $\mathrm{D}$ et al (2008). Control of hormonal stress reactivity by the endogenous opioid system. Psychoneuroendocrinology 33: 425-436.

Brunello N, Blier P, Judd LL, Mendlewicz J, Nelson CJ, Souery D et al (2003). Noradrenaline in mood and anxiety disorders: basic and clinical studies. Int Clin Psychopharmacol 18: 191-202.

Coste SC, Kesterson RA, Heldwein KA, Stevens SL, Heard AD, Hollis $\mathrm{JH}$ et al (2000). Abnormal adaptations to stress and impaired cardiovascular function in mice lacking corticotropinreleasing hormone receptor-2. Nat Genet 24: 403-409.

Crawley JN (1999). Behavioral phenotyping of transgenic and knockout mice: experimental design and evaluation of general health, sensory functions, motor abilities, and specific behavioral tests. Brain Res 835: 18-26.

Ebner K, Rupniak NM, Saria A, Singewald N (2004). Substance P in the medial amygdala: emotional stress-sensitive release and modulation of anxiety-related behavior in rats. Proc Natl Acad Sci USA 101: 4280-4285.

Ebner K, Singewald N (2006). The role of substance P in stress and anxiety responses. Amino Acids 31: 251-272.

Engelhardt G, Homma D, Schlegel K, Schnitzler C, Utzmann R (1996). General pharmacology of meloxicam - Part I: effects on CNS, gastric emptying, intestinal transport, water, electrolyte and creatinine excretion. Gen Pharmacol 27: 673-677.

Gavioli EC, Canteras NS, De Lima TC (1999). Anxiogenic-like effect induced by substance $P$ injected into the lateral septal nucleus. Neuroreport 10: 3399-3403.

Graeff FG (2002). On serotonin and experimental anxiety. Psychopharmacology (Berl) 163: 467-476.

Hamke M, Herpfer I, Lieb K, Wandelt C, Fiebich BL (2006). Substance $\mathrm{P}$ induces expression of the corticotropin-releasing factor receptor 1 by activation of the neurokinin-1 receptor. Brain Res 1102: 135-144.

Heilig M, Koob GF, Ekman R, Britton KT (1994). Corticotropinreleasing factor and neuropeptide $\mathrm{Y}$ : role in emotional integration. Trends Neurosci 17: 80-85.

Holm S (1979). A simple sequentially rejective multiple test procedure. Scand J Stat 6: 65-70.

Jewett DC, Grace MK, Jones RM, Billington CJ, Portoghese PS, Levine AS (2001). The kappa-opioid antagonist GNTI reduces U50,488-, DAMGO-, and deprivation-induced feeding, but not butorphanol- and neuropeptide Y-induced feeding in rats. Brain Res 909: 75-80.

Jones RM, Portoghese PS (2000). 5'-Guanidinonaltrindole, a highly selective and potent kappa-opioid receptor antagonist. Eur $J$ Pharmacol 396: 49-52.

Karl T, Pabst R, von Horsten S (2003). Behavioral phenotyping of mice in pharmacological and toxicological research. Exp Toxicol Pathol 55: 69-83.

Karlsson RM, Choe JS, Cameron HA, Thorsell A, Crawley JN, Holmes A et al (2008). The neuropeptide Y Y1 receptor subtype is necessary for the anxiolytic-like effects of neuropeptide $\mathrm{Y}$, but 
not the antidepressant-like effects of fluoxetine, in mice. Psychopharmacology (Berl) 195: 547-557.

Kask A, Harro J, von Horsten S, Redrobe JP, Dumont Y, Quirion R (2002). The neurocircuitry and receptor subtypes mediating anxiolytic-like effects of neuropeptide Y. Neurosci Biobehav Rev 26: 259-283.

Kask A, Schioth HB, Mutulis F, Wikberg JE, Rago L (2000). Anorexigenic cocaine- and amphetamine-regulated transcript peptide intensifies fear reactions in rats. Brain Res 857: 283-285.

Kishimoto T, Radulovic J, Radulovic M, Lin CR, Schrick C, Hooshmand F et al (2000). Deletion of crhr2 reveals an anxiolytic role for corticotropin-releasing hormone receptor-2. Nat Genet 24: 415-419.

Knoll AT, Meloni EG, Thomas JB, Carroll FI, Carlezon WA (2007). Anxiolytic-like effects of $\{k a p p a\}$-opioid receptor antagonists in models of unlearned and learned fear in rats. J Pharmacol Exp Ther 323: 838-845.

Kudryavtseva NN, Gerrits MA, Avgustinovich DF, Tenditnik MV, Van Ree JM (2004). Modulation of anxiety-related behaviors by mu- and kappa-opioid receptor agonists depends on the social status of mice. Peptides 25: 1355-1363.

Kuzmin A, Madjid N, Terenius L, Ogren SO, Bakalkin G (2006). Big dynorphin, a prodynorphin-derived peptide produces NMDA receptor-mediated effects on memory, anxiolytic-like and locomotor behavior in mice. Neuropsychopharmacology 31: 1928-1937.

Land BB, Bruchas MR, Lemos JC, Xu M, Melief EJ, Chavkin C (2008). The dysphoric component of stress is encoded by activation of the dynorphin kappa-opioid system. J Neurosci 28 : 407-414.

Lin S, Boey D, Lee N, Schwarzer C, Sainsbury A, Herzog H (2006). Distribution of prodynorphin mRNA and its interaction with the NPY system in the mouse brain. Neuropeptides 40: $115-123$.

Loacker S, Sayyah M, Wittmann W, Herzog H, Schwarzer C (2007). Endogenous dynorphin in epileptogenesis and epilepsy: anticonvulsant net effect via kappa opioid receptors. Brain 130: 1017-1028.

Marchant NJ, Densmore VS, Osborne PB (2007). Coexpression of prodynorphin and corticotrophin-releasing hormone in the rat central amygdala: evidence of two distinct endogenous opioid systems in the lateral division. J Comp Neurol 504: 702-715.

McLaughlin JP, Marton-Popovici M, Chavkin C (2003). Kappa opioid receptor antagonism and prodynorphin gene disruption block stress-induced behavioral responses. J Neurosci 23: 5674-5683.

Narita M, Kaneko C, Miyoshi K, Nagumo Y, Kuzumaki N, Nakajima $M$ et al (2006). Chronic pain induces anxiety with concomitant changes in opioidergic function in the amygdala. Neuropsychopharmacology 31: 739-750.

Olivier B, Zethof T, Pattij T, van Boogaert M, van Oorschot R, Leahy C et al (2003). Stress-induced hyperthermia and anxiety: pharmacological validation. Eur J Pharmacol 463: 117-132.

Sainsbury A, Schwarzer C, Couzens M, Herzog H (2002). Y2 receptor deletion attenuates the type 2 diabetic syndrome of ob/ob mice. Diabetes 51: 3420-3427.
Sajdyk TJ, Shekhar A, Gehlert DR (2004). Interactions between NPY and CRF in the amygdala to regulate emotionality. Neuropeptides 38: 225-234.

Schoffelmeer AN, Hogenboom F, Mulder AH (1997). Kappa1- and kappa2-opioid receptors mediating presynaptic inhibition of dopamine and acetylcholine release in rat neostriatum. $\mathrm{Br}$ Pharmacol 122: 520-524.

Schwarzer C, Kofler N, Sperk G (1998). Up-regulation of neuropeptide Y-Y2 receptors in an animal model of temporal lobe epilepsy. Mol Pharmacol 53: 6-13.

Sharifi N, Diehl N, Yaswen L, Brennan MB, Hochgeschwender U (2001). Generation of dynorphin knockout mice. Brain Res $\mathrm{Mol}$ Brain Res 86: 70-75.

Shepard JD, Barron KW, Myers DA (2000). Corticosterone delivery to the amygdala increases corticotropin-releasing factor mRNA in the central amygdaloid nucleus and anxiety-like behavior. Brain Res 861: 288-295.

Smith GW, Aubry JM, Dellu F, Contarino A, Bilezikjian LM, Gold LH et al (1998). Corticotropin releasing factor receptor 1-deficient mice display decreased anxiety, impaired stress response, and aberrant neuroendocrine development. Neuron 20: 1093-1102.

Solbrig MV, Adrian R, Baratta J, Lauterborn JC, Koob GF (2006). Kappa opioid control of seizures produced by a virus in an animal model. Brain 129: 642-654.

Stanek LM (2006). Cocaine- and amphetamine related transcript (CART) and anxiety. Peptides 27: 2005-2011.

Stenzel-Poore MP, Duncan JE, Rittenberg MB, Bakke AC, Heinrichs SC (1996). CRH overproduction in transgenic mice: behavioral and immune system modulation. Ann NY Acad Sci 780: $36-48$.

Timpl P, Spanagel R, Sillaber I, Kresse A, Reul JM, Stalla GK et al (1998). Impaired stress response and reduced anxiety in mice lacking a functional corticotropin-releasing hormone receptor 1. Nat Genet 19: 162-166.

Tsuda M, Suzuki T, Misawa M, Nagase H (1996). Involvement of the opioid system in the anxiolytic effect of diazepam in mice. Eur J Pharmacol 307: 7-14.

Vlachakis ND, De Guia D, Mendlowitz M, Antram S, Wolf RL (1974). Hypertension and anxiety. A trial with epinephrine and norepinephrine infusion. Mt Sinai J Med 41: 615-625.

Wahlestedt C, Pich EM, Koob GF, Yee F, Heilig M (1993). Modulation of anxiety and neuropeptide Y-Y1 receptors by antisense oligodeoxynucleotides. Science 259: 528-531.

Wang Z, Gardell LR, Ossipov MH, Vanderah TW, Brennan MB, Hochgeschwender $U$ et al (2001). Pronociceptive actions of dynorphin maintain chronic neuropathic pain. J Neurosci 21: 1779-1786.

Westenberg HG, den Boer JA, Kahn RS (1987). Psychopharmacology of anxiety disorders: on the role of serotonin in the treatment of anxiety states and phobic disorders. Psychopharmacol Bull 23: 145-149.

Wise CD, Berger BD, Stein L (1970). Serotonin: a possible mediator of behavioral suppression induced by anxiety. Dis Nerv Syst 31(Suppl): 34-37.

Wollemann M, Benyhe S (2004). Non-opioid actions of opioid peptides. Life Sci 75: 257-270.

Supplementary Information accompanies the paper on the Neuropsychopharmacology website (http://www.nature.com/npp) 